\title{
Gambaran Pencabutan Gigi Di Balai Pengobatan Rumah Sakit Gigi Dan Mulut Universitas Sam Ratulangi Tahun 2012
}

\author{
${ }^{1}$ Rilly Sylvester Ngangi, ${ }^{2}$ Ni Wayan Mariati, ${ }^{2}$ Bernat S.P. Hutagalung \\ ${ }^{1}$ Mahasiswa Program Studi Kedokteran Gigi Fakultas Kedokteran \\ Universitas Sam Ratulangi Manado \\ ${ }^{2}$ Dosen di Program Studi Kedokteran Gigi Fakultas Kedokteran Universitas Sam Ratulangi \\ Email :realize_joe@yahoo.com
}

\begin{abstract}
ABSTRAK
Pencabutan gigi merupakan suatu tindakan mengeluarkan gigi dari soket tulang alveolar.Faktor yang seringkali menjadi indikasi pencabutan gigi ialah karies, dan penyakit periodontal.Kehilangan gigi dapat menjadi kerugian bagi pasien karena dapat mengurangi efisiensi pengunyahan, malposisi gigi, masalah pada temporo mandibular joint, dan masalah di dalam rongga mulut lainnya. Sekarang ini angka kasus pencabutan gigi masih terbilang tinggi, sehingga menjadi tugas penting bagi seluruh lapisan masyarakat untuk membangun perilaku sadar akan kesehatan gigi dan mulut. Tujuan penelitian ini untuk mengetahui gambaran pencabutan gigi di Balai Pengobatan Rumah Sakit Gigi Mulut Universitas Sam Ratulangi pada tahun 2012.Penelitian ini bersifat deskriptif dengan jenis penelitian retrospektif.Pengambilan sampel menggunakan teknik total samplingdimana tercatat ada 1389 kasus pencabutan gigi pada tahun 2012. Hasil penelitian menunjukan kasus pencabutan gigi paling tinggi terdapat pada kelompok usia dewasa yaitu berjumlah 837 kasus $(60.25 \%)$, dan jumlah kasus pencabutan gigi untuk jenis kelamin perempuan lebih tinggi yaitu sebesar 455 kasus $(62.51 \%)$ dibandingkan dengan laki-laki yang berjumlah 310 kasus (37.49\%). Jenis gigi permanen yang paling banyak dicabut ialah gigi molar pertama rahang bawah sebesar 167 kasus (12.02\%).Jenis gigi desidui yang paling banyak dicabut ialah molar kedua rahang bawah sebesar 45 kasus (3.31\%). Kasus pencabutan gigi dengan diagnosis nekrosis pulpa mempunyai frekuensi paling tinggi yaitu sebesar 787 kasus (56.65\%), sedangkan frekuensi kasus dengan diagnosis paling rendah ialah gigi impaksi yang hanya berjumlah satu kasus $(0.07 \%)$.
\end{abstract}

Kata kunci : Pencabutan gigi, karies, periodontitis, pulpitis

\begin{abstract}
Tooth extraction is a procedure of pulling out the teeth from the alveolar bone socket. Extractions were mostly happened because of caries and, periodontal diseases. Tooth loss can be a detriment to the patient because it can reduce the efficiency of mastication, malpositioned teeth, temporo mandibular joint problems, and other problems in the oral cavity. The number of tooth extraction is still high until now, so it become an important thing for the whole society to build a conscious behavior of oral health. Objective of this study to describe the extraction of teeth at Balai Pengobatan Rumah Sakit Gigi Mulut Universitas Sam Ratulangi in 2012. This research is a descriptive study with a type of retrospective study and use total sampling method. There are 1389 cases of tooth extraction in 2012. The results showed cases of tooth extraction in adults were the highest, total 837 cases (60.25\%), and the number of cases for female gender was higher (455 cases, 62.51\%) than men (310 cases, 37.49\%). the most frequent extracted permanent tooth was mandibular first molar (167 cases, 12.02\%), and for primary tooth was mandibular second molar (45 cases, 3.31\%). pulp necrosis were the most frequent diagnosis that cause tooth extraction in this study (787 cases, 56.65\%) and the fewest were impacted teeth that only one case founded.
\end{abstract}

Keyword: tooth extraction, caries, periodontitis, pulpitis

\section{PENDAHULUAN}

Pencabutan gigi merupakan suatu tindakan mengeluarkan gigi dari soket tulang alveolar. Pencabutan gigi paling banyak dilakukan karena karies, selain karies ada penyakit periodontal, supernumerary teeth, gigi impaksi, gigi yang sudah tidak dapat lagi dilakukan perawatan endodontik, gigi yang terlibat kista dan tumor, gigi yang terlibat fraktur rahang. Tindakan pencabutan gigi dapat dilakukan juga pada gigi sehat dengan tujuanmemperbaiki maloklusi, untuk alasan estetik, dan juga kepentingan perawatan orthodontik atau prostodontik. Pencabutan gigi terkadang tidak bisa dilakukan karena berbagai faktor, seperti kelainan sistemik 
(diabetes melitus, hipertensi, leukemia yang tidak terkontrol, kehamilan, kelainan perdarahan) dan kelainan lokal (perikoronitis akut, oedem berat, abses dentoalveolar akut, dan sebagainya). ${ }^{1,2}$

Tindakan pencabutan gigi merupakan pilihan terakhir bilamana gigi pasien sudah rusak dan tidak dapat dirawat lagi. Banyak diantara kalangan masyarakat yang sudah mengerti akan pentingnya mempertahankan gigi didalam rongga mulut, namun tidak sedikit juga yang masih belum mengerti dan cenderung untuk mencabut gigi yang rusak daripada merawat gigi. Kurangnya edukasi akan kesehatan gigi dan mulut merupakan salah satu faktor yang mempengaruhi orang untuk mencabut gigi yang masih bisa dipertahankan. Kehilangan gigi dapat menjadi kerugian bagi pasien karena dapat mengurangi efisiensi pengunyahan, migrasi dan rotasi gigi, masalah pada temporo mandibular joint (TMJ), dan masalah didalam rongga mulut lainnya. ${ }^{3}$

Masalah kesehatan gigi di Indonesia dapat dikatakan tinggi. Berdasarkan Riskesdas 2007, prevalensi masalah gigi nasional sebesar 23,5\%. Provinsi Sulawesi utara merupakan salah satu provinsi yang mempunyai masalah gigi diatas rata rata nasional yaitu 29,8\%. Khusus Kota Manado, kasus pencabutan gigi di seluruh puskesmas yang terdapat di 9 kecamatan ada 2296 kasus pada tahun 2011.,

Masalah kesehatan gigi dan mulut sangat mempengaruhi tingginya angka pencabutan gigi sehingga menjadi tugas penting bagi seluruh lapisan masyarakat untuk membangun perilaku sadar akan kesehatan gigi dan mulut.Penelitian ini dilakukan di Balai Pengobatan Rumah Sakit Gigi Mulut (BP-RSGM) Universitas Sam Ratulangi dan bertujuan untuk mengetahui gambaran pencabutan gigi yang dilakukan pada tahun 2012.

\section{METODE PENELITIAN}

Penelitian ini merupakan penelitian deskriptif dengan menggunakan pendekatan retrospektif. Pengambilan sampel dalam penelitian ini dilakukan dengan metode total sampling dimana sampel ialah seluruh kartu status pasien yang melakukan tindakan pencabutan gigi di BP-RSGM Sam Ratulangi pada tahun 2012. Subjek penelitian ini berupa data sekunder yang didapat dari kartu status kesehatan pasien yang berobat di BP-RSGM Universitas Sam Ratulangi pada tahun 2012.

Variabel penelitian ini yaitu pencabutan gigi, usia, jenis kelamin, jenis gigi, dan diagnosis. Pada kelompok usia terbagi atas empat kelompok yaitu anak ( $\leq 12$ tahun), remaja (13-18 tahun), dewasa (19-55 tahun), Lansia ( $\geq$ 56 tahun). Jenis gigi dibagi menjadi dua kategori yaitu gigi desidui dan gigi permanen.Gigi desidui terdiri dari insisivus, kaninus,molar sedangkan gigi permanen terdiri dari insisivus, kaninus, premolar dan molar.Diagnosis dalam penelitian ini terdiri dari pulpitis ireversibel, pulpitis hiperplastik, nekrosis pulpa, periodontitis marginalis kronis, persistensi, ulcus decubitus, supernumerary teeth dan impaksi. Selain yang disebutkan, akan dimasukan dalam kelompok lain-lain. Pengambilan data menggunakan formulir tabel isian dan kartu status pasien

\section{HASIL PENELITIAN}

Berdasarkan penelitian terhadap 1389 kartu status pasien, terdapat 1389 kasus pencabutan gigi dan 765 pasien yang merupakan pasien tindakan pencabutan gigi. Dilihat dari 1389 kasus tindakan pencabutan gigi, kelompok usia yang paling banyak melakukan pencabutan gigi yaitu kelompok usia dewasa sebanyak 837 kasus $(60.25 \%)$ (Gambar 1).

Gambar 1. Distribusi kasus pencabutan gigi berdasarkan usia

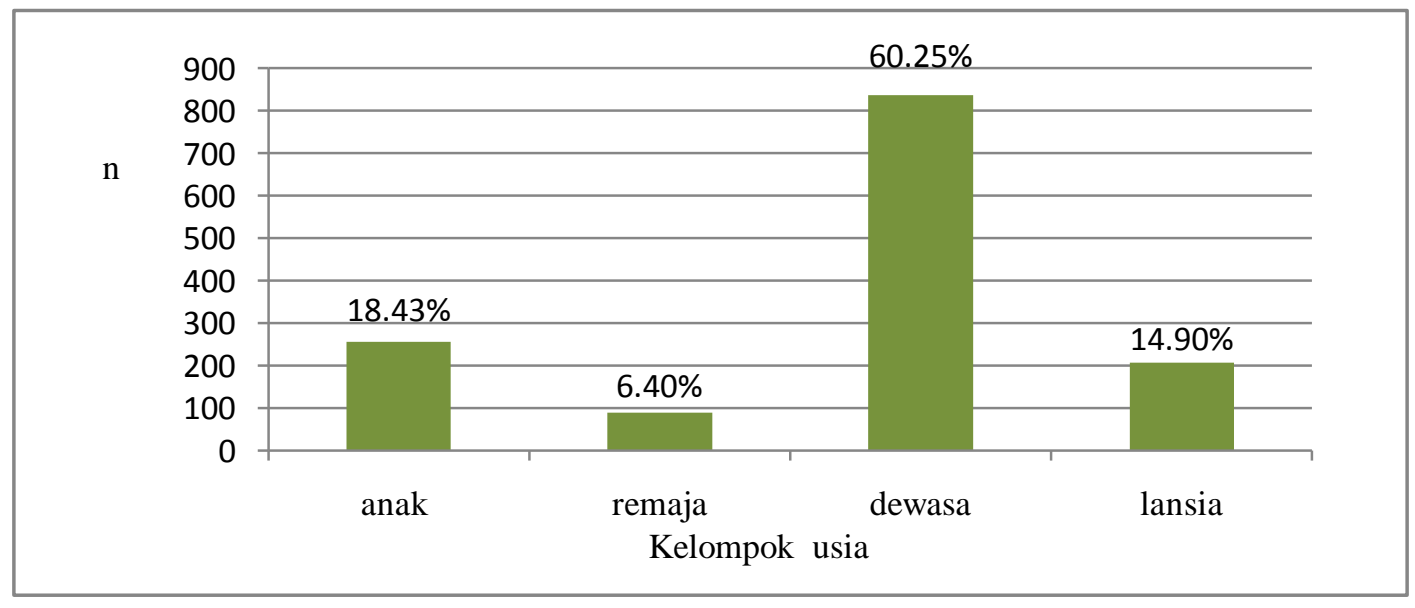


Data diatas menggambarkan kasus pencabutan gigi pada kelompok usia anak menempati urutan kedua, diikuti kelompok usia lansia, dan kelompok usia remaja merupakan kelompok usia dengan kasus pencabutan paling sedikit yaitu sebesar 89 kasus (6.40\%) (Gambar 1).

Berdasarkan jenis kelamin, pasien dengan jenis kelamin perempuan lebih banyak melakukan tindakan pencabutan gigi dibandingkan laki-laki (Gambar 2).

Gambar 2.Distribusi kasus pencabutan gigi berdasarkan jenis kelamin.

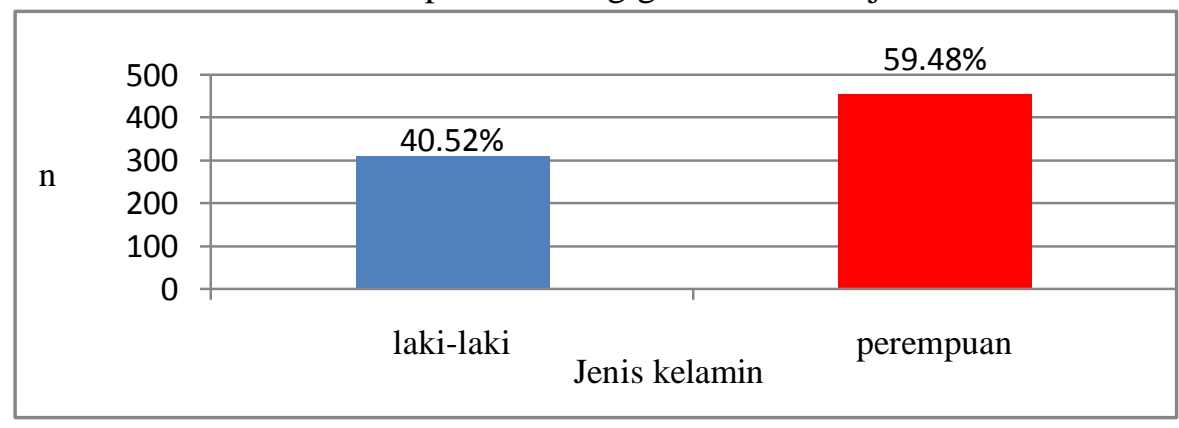

Berdasarkan jenis gigi dibagi menjadi dua yaitu gigi permanen dan gigi desidui. Hasil pencabutan pada gigi permanen menggambarkan bahwa gigi yang paling banyak dicabut yaitu gigi molar pertama rahang bawah sebesar 167 kasus (14.7\%), diikuti insisivus pertama rahang atas, dan yangketiga terbanyak yaitu insisivus kedua rahang atas. Molar ketiga rahang atas merupakan gigi yangpaling sedikit dicabut dengan jumlah 25 kasus (2.2\%) (Gambar 3).

Gambar 3. Distribusi frekuensi kasus pencabutan gigi permanen

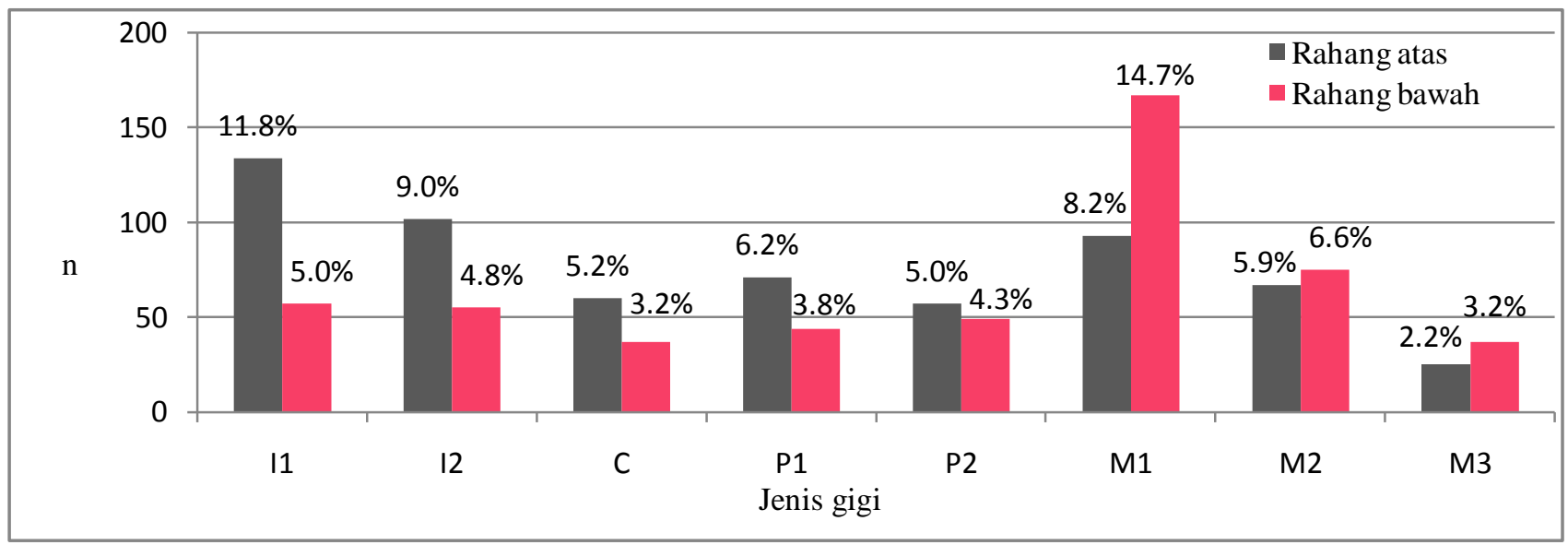

Hasil pencabutan pada gigi desidui menggambarkan bahwa gigi yang paling banyak dicabut yaitu gigi molar kedua rahang bawah yaitu sebesar 46 kasus (17.9\%), diikuti molar kedua rahang bawah. Gigi yang paling sedikit dicabut ialah gigi molar pertama rahang atas dengan jumlah 11 kasus (4.2\%) (Gambar 4).

Gambar 4. Distribusi frekuensi kasus pencabutan gigi desidui

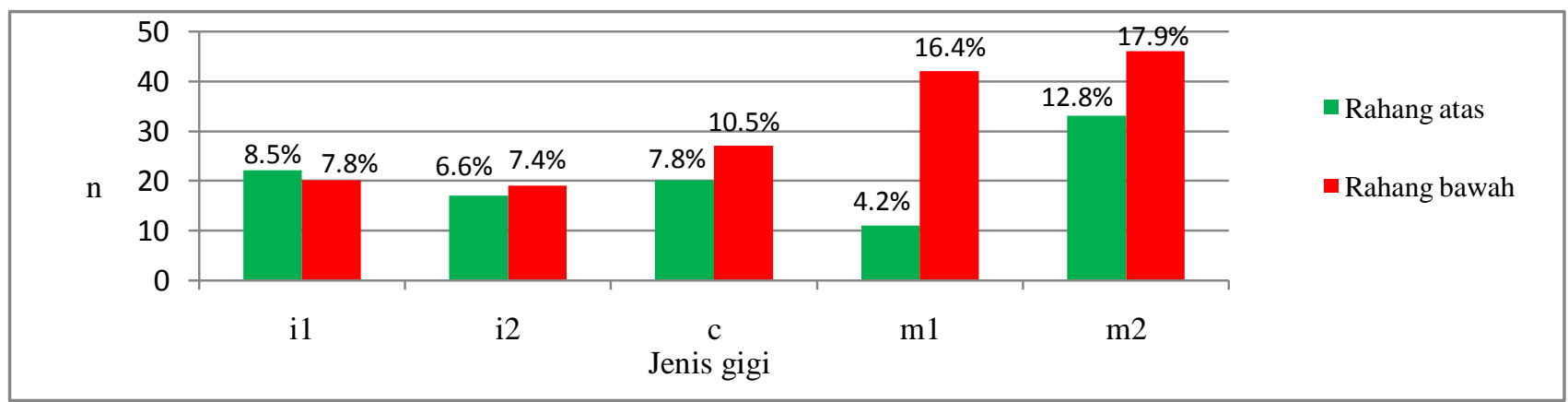


Berdasarkan penelitian, kasus pencabutan gigi untuk regio maksila atau rahang atas lebih sedikit dibandingkan mandibula atau rahang bawah.Dilihat dari regio anterior-posterior, kasus pencabutan gigi lebih banyak di regio posterior dibandingkan regio anterior (Gambar 5).

Gambar 5. Distribusi frekuensi kasus pencabutberdasarkan regio

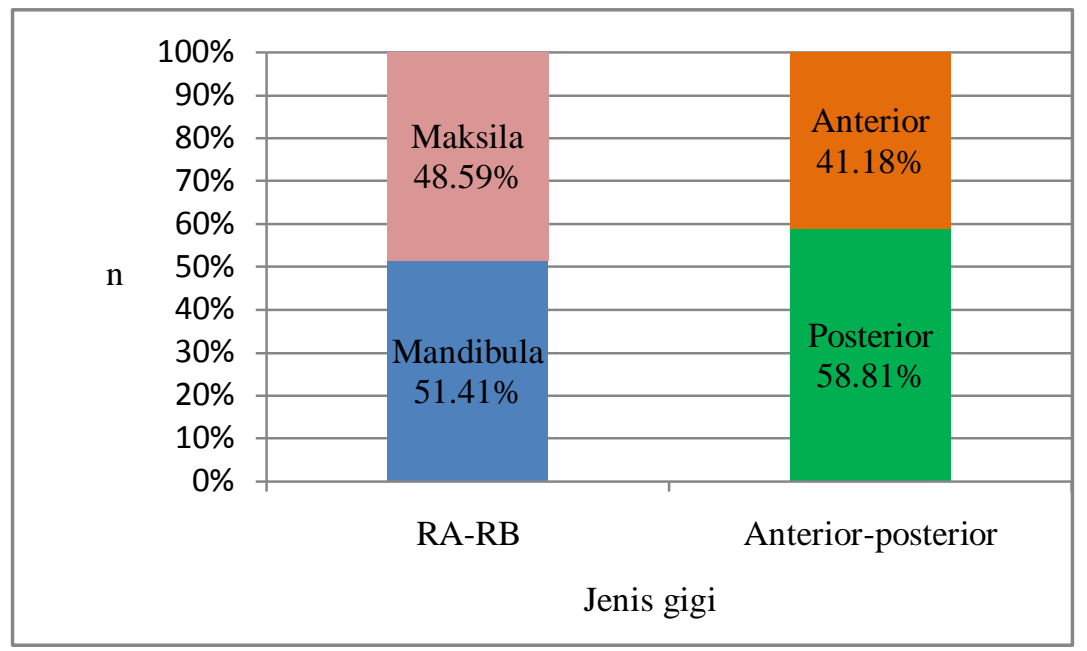

Berdasarkan diagnosis, ditemukan bahwa diagnosis nekrosis pulpa merupakan diagnosis pencabutan tertinggi dengan jumlah 787 kasus(56.65\%) dan kedua tertinggi yaitu periodontitismarginalis kronis dengan jumlah 163 kasus (12.95\%) (Gambar 6).

Gambar 6. Distribusi frekuensi kasus pencabutan gigi berdasarkandiagnosis

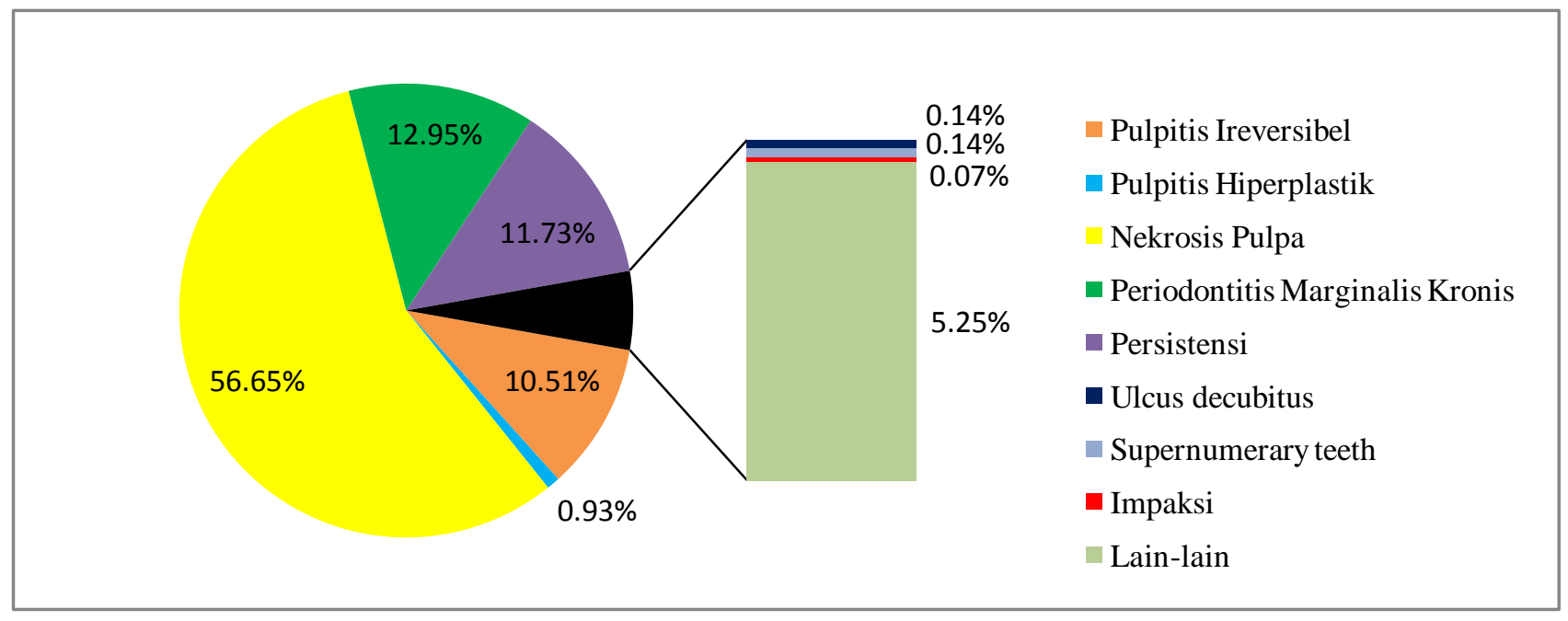

\section{PEMBAHASAN}

Berdasarkan penelitian yang telah dilakukan, kelompok usia yang mempunyai kasus terbanyak ialah kelompok usia dewasa, hal ini cukup wajar mengingat rentang usia dewasa cukup besar jika dibandingkan dengan kelompok usia lainnya. Rentang usia kelompok dewasa yaitu dari 19 hingga 55 tahun. Hasil ini serupa dengan hasil penelitian Kusumaningrum yang meneliti tentang pencabutan gigi di Rumah Sakit Gigi dan Mulut pendidikan (RSGMP) Fakultas Kedokteran Gigi (FKG) Universitas Indonesia. Kusumangingrum mendapatkan bahwa pencabutan gigi pada pasien dewasa memiliki prevalensi yang tinggi, yaitu sebesar $83.7 \%{ }^{6}$

Rentang usia yang dimaksudkan sebelumnya bukanlah faktor yang menentukan tingginya kasuspencabutan di kelompok usia dewasa, namun faktor-faktor yang mempengaruhi dapat seperti oral hygiene yang buruk, kesadaran akan merawat gigi yang kurang, kurangnya dental health education (DHE), dan faktor lainnya. Gigi 
geligi pada kelompok usia dewasa seringkali sudah terkena berbagai penyakit, seperti pulpitis ireversibel, hingga nekrosis pulpa, selain itu pada usia diatas 40 tahun sudah banyak gigi yang dicabut karena penyakit periodontal.

Pencabutan gigi pada kelompok usia remaja memiliki jumlah paling sedikit dalam penelitian ini, hal ini bisa disebabkan karena sebagian besar gigi geligi pada kelompok usia remaja baru berganti menjadi gigi permanen. Hal ini menyebabkan gigi belum banyak terkena akumulasi penyakit seperti karies.

Berdasarkan penelitian yang dilakukan, didapat bahwa kasus pencabutan gigi untuk jenis kelamin perempuan lebih banyak daripada jenis kelamin laki-laki.Secara keseluruhan, persentase kasus perempuan lebih besar yaitu $62.51 \%$ dibandingkan jenis kelamin laki-laki hanya 37.49\%. Penelitian yang dilakukan oleh Al Qudah di Yordania mendapatkan bahwa tidak ada perbedaan signifikan antara jumlah pasien laki-laki sebesar 258 pasien dan perempuan sebesar 254 pasien, sedangkan penelitian yang dilakukan oleh Affonso di Brazil mendapatkan bahwa jumlah pasien laki-laki lebih tinggi yaitu sebanyak 237 pasien sedangkan perempuan 202 pasien.

Prevalensi pada jenis kelamin perempuan bisa lebih tinggi jika dibandingkan pada jenis kelamin laki-laki. Hal ini bisa disebabkan karena pada perempuan terdapat faktor hormonal yang menyebabkan perempuan lebih rentan terhadap masalah didalam rongga mulut misalnya gingivitisatau karies. Pada saat siklus menstruasi, hormon estrogen dapat memicu timbulnya gingivitis, selain itu tingkat keasaman (ph) dalam rongga mulut juga berubah menjadi asam, hal inilah yang memicu timbulnya karies. ${ }^{7,8,9}$

Perbandingan jumlah kasus antara laki-laki dan perempuan berbeda-beda di tiap daerah tergantung situasi dan kondisi daerah tersebut. Jumlah kasus perempuan yang lebih banyak di BP-RSGM bisa disebabkan oleh kurangnya sifat acak/random karena pasien sebagian besar didatangkan oleh mahasiswa yang mengerjakan requirement bagian pencabutan gigi.

Berdasarkan penelitian yang telah dilakukan, jenis gigi permanen yang paling banyak dicabut ialah molar pertama kiri bawah.Hal ini serupa dengan hasil penelitian yang dilakukan oleh Salewedi RSGMP FKGUniversitas Hassanudin yang mendapatkan bahwa gigi yang paling banyak dicabut ialah molar pertama rahang bawah. Molar pertama merupakan gigi permanen yang pertama kali erupsi. Molar pertama permanen erupsi pada kisaran usia 6-7 tahun, baik itu molar bawah atau molar atas. Jika dibandingkan dengan waktu erupsi gigi permanen lainnya, maka molar pertama sangat rentan terhadap karies. Selain itu faktor anatomi gigi molar sangat berpengaruh terhadap perkembangan karies. Adanya fisur pada daerah oklusal gigi molar lebih memudahkan bakteri untuk berkembang biak. ${ }^{7,10}$

Berdasarkan data hasil penelitian, gigi yang paling banyak dicabut setelah molar pertama rahang bawah ialah gigi insisivus pertama rahang atas. Hal ini bisa disebabkan karena gigi insisivus pertama memiliki waktu erupsi pada umur 7-8 tahun. Waktu erupsi yang lebih awal dibandingkan gigi lainnya menyebabkan gigi lebih rentanterhadap manifestasi karies.

Penelitian ini juga menunjukan bahwa pada kelompok usia anak-anak, gigi yang paling banyak dicabut ialah gigi molar kedua dan pertama rahang bawah. Hal ini serupa dengan kasus molar pertama rahang bawah pada gigi permanen. Anatomi gigi molar menyebabkan karies berkembang lebih cepat, selain itu letak gigi yang lebih dibelakang lebih menyulitkan untuk dibersihkan pada saat menyikat gigi.

Distribusi pencabutan gigi pada regio rahang bawah lebih tinggi prevalensinya dibandingkan rahang atas. Hal ini bisa disebabkan waktu erupsi

gigi geligi rahang bawah lebih awal sehingga akumulasi bakteri lebih banyak. Prevalensi gigi geligi pada regio superior lebih tinggi dibandingkan anterior. Hal ini disebabkan gigi geligi posterior lebih sulit dibersihkan dibandingkan gigi geligianterior, selain itu faktor anatomi juga berpengaruh dimana gigi geligi posterior memiliki banyak fisur.

Berdasarkan penelitian yang telah dilakukan, didapatkan bahwa nekrosis pulpa merupakan diagnosis terbanyak dalam kasus pencabutan gigi di BP-RSGM. Dari 1389 kasus, tercatat ada $787(56.65 \%)$ kasus pencabutan dengan diagnosis nekrosis pulpa, diikuti oleh periodontitis marginalis kronis 163 kasus (11.73\%), lalu 141 kasus pulpitis ireversibel $(10.51 \%)$. Sebelumnya telah dibahas bahwa nekrosis pulpa merupakan indikasi yang paling sering dijumpai pada kasus pencabutan gigi. Nekrosis dapat berawal dari pulpitis reversible, kemudian berkembang menjadi pulpitis ireversibel dan akhirnya menjadi nekrosis pulpa. Hal ini bisa disebabkan oleh oral hygiene yang buruk, kesadaran akan merawat gigi yang kurang, kurangnya DHE, dan faktor lainnya. ${ }^{11}$

Diagnosis kedua tertinggi ialah PMK. Penyakit periodontal merupakan masalah kesehatan gigi dan mulut yang memiliki prevalensi cukup tinggi di masyarakat dengan prevalensi penyakit periodontal pada semua kelompok usia di indonesia adalah 96,58\%. Salah satu komplikasi diabetes melitus yang cukup serius di bidang kedokteran gigi adalah oral diabetic, yang meliputi mulut kering (xerostomia), (gingivitis), kalkulus, resorbsi tulang 
alveolaris, periodontitis dan lain sebagainya. Dari sekian banyak komplikasi yang terjadi, periodontitis merupakan komplikasi yang paling sering terjadi pada penderita diabetes melitus. Hal ini berkaitan dengan hasil penelitian ini, dimana sebagian besar pasien kasus PMK berusia empat puluh tahun keatas dan kebanyakan memiliki riwayat diabetes melitus. ${ }^{12,13,14}$

Pada kelompok usia anak-anak, diagnosis terbanyak dari kasus pencabutan gigi ialah persistensi sebanyak 161 kasus $(62.89 \%)$. Hal ini menggambarkan bahwa anak2 membutuhkan perhatian khusus dan perawatan preventif karena kasus persistensi bisa berpengaruh pada erupsi gigi, contohnya, malposisi, maloklusi, gigi berjejal, dan lain-lain. Diagnosis kedua terbanyak ialah nekrosis pulpa sebanyak 59 kasus (23.04\%). Hal ini dapat menggambarkan bahwa masih minimnya kesadaran anak-anak untuk menjaga oral hygiene, dan juga kurangnya peran orang tua untuk memberi pengarahan tentang pentingnya menjaga kebersihan gigi dan mulut kepada anaknya.

\section{KESIMPULAN}

Kasus pencabutan gigi paling tinggi terdapat pada kelompok usia dewasa dan yang paling rendah ialah kelompok usia remaja. Jumlah kasus pencabutan gigi untuk jenis kelamin perempuan lebih tinggi dibandingkan dengan laki-laki.Jenis gigi permanen yang paling banyak dicabut ialah gigi molar pertama rahang bawah sedangkan yang paling sedikit dicabut ialah molar ketiga rahang atas.Jenis gigi desidui yang paling banyak dicabut ialah molar kedua rahang bawah sedangkan yang paling sedikit ialah molar pertama rahang atas.Frekuensi pencabutan gigi pada regio mandibula lebih tinggi dibandingkan regio maksila, dan regio anterior lebih tinggi frekuensinya dibandingkan regio posterior.Kasus pencabutan gigi dengan diagnosis nekrosis pulpa mempunyai frekuensi paling tinggi, diikuti periodontitis marginalis kronis sedangkan frekuensi kasus dengan diagnosis paling rendah ialah gigi impaksi yang hanya berjumlah satu kasus.

\section{SARAN}

Diharapkan penelitian ini bisa digunakan sebagai informasi yang bisa digunakan dalam meningkatkan mutu pelayanan atau perencanaan sosialisasi kesehatan gigi dan mulut kepada pasien.

\section{DAFTAR PUSTAKA}

1. Fragiskos. Oral surgery. Berlin : Verlag Berlin Heidelberg; 2007. hal. 1-28

2. U.J. Moore. Principles of Oral maxillofacial surgery $6^{\text {th }}$ ed. Chichester: Wiley Blackwell: 2011. hal. 24-42, 156-75

3. Darmawan. Akibat dari kehilangan gigi [online]. 2011 [cited 2013 july] ; available from : http://www.scribd.com/doc/70919825/Akibat-Dari-Kehilangan-Gigi

4. Riskesdas. [online] 2007 [cited $2011 \quad$ March 15]. Available from: http//www.litbang.depkes.go.id/simnas4/day.2/gigi.pdf

5. Laporan data pelayanan kesehatan gigi dan mulut. Dinas kesehatan kota Manado. Manado. 2013

6. Kusumaningrum A. Frekuensi distribusi edema dan dry socket pasca ekstraksi padapasien usia 17-76 tahun di rumah sakit gigi dan mulut pendidikan fakultas kedokteran gigi universitas Indonesia periode januari 2003-oktober 2008 [online]. 2008 [cited 2012 may]; available from : http://www.digilib.ui.ac.id/opac/themes/libri2/digitalfiles.jsp?id=125153\&lokasi=lokal

7. Affonso A.Prevalence and reasons for tooth loss in a sample from a dental clinic in brazil. International journal of dentistry volume 2012 [online]. 24 july 2012 [cited spetember 2013]; available from http://www.hindawi.com/journals/ijd/2012/719750/

8. Al Qudah M. The reasons for dental extraction of permanent teeth in a jordanian population, including considerations for the influence of social factors [online]. 2004 [cited September 2013]; availabre from: http://www.smiledentaljournal.com/images/stories/Volume_7_Issue_1/The_Reasons_for_Dental_Extraction of Permanent Teeth.pdf

9. Schurs h.b. Patologi gigi geligi, kelainan-kelainan jaringan keras gigi. Gajah mada university press. hal. 134162

10. Salewe Y. Prevalensi pencabutan gigi di rumah sakit gigi dan mulut FKG-UH periode 2005-2009 [online]. 2012 [cited 2013 october]; available from: http://repository.unhas.ac.id/handle/123456789/830

11. Tarigan R. Perawatan pulpa gigi (endodonti) $2^{\text {nd }}$ ed. Jakarta.; EGC. 2004. hal.33-6 
12. Tampubolon, Situmorang N. Dampak karies gigi dan penyakit periodontal terhadap kualitas hidup [online]. November 2010 [cited September 2013] available from: http://library.usu.ac.id.

13. Hidayati Sri, Muafiro, Suwito. Analisis faktor yang berhubungan dengan tingkat keparahan periodontitis pada penderita dm tipe 2 di poli diabetes rsu dr. soetomo surabaya. Buletin penelitian rsu dr. soetomo vol 10 no.2. 2008.

14. Nandya, Erni maduratna ,Augustina Eka. Status kesehatan jaringan periodontal pada pasien diabetes mellitus tipe 2 dibandingkan dengan pasien non diabetes mellitus berdasarkan gpi [online]. 2011[cited September 2013]. Available from: http://journal.unair.ac.id/filerpdf/ejournal $\% 20$ status $\% 20$ kesehatan $\% 20$ jaringan $\% 20$ periodontal.pdf 